\title{
THE PREFERENCES AND DISTRIBUTION OF SUGARCANE SCALE INSECT Aulacaspis tegalensis (HEMIPTERA: DIASPIDIDAE) ON DIFFERENT CLONES OF SUGARCANE
}

\author{
Sudi Pramono ${ }^{1}$, Franciscus Xaverius Wagiman ${ }^{2}$, Yohanes Andi Trisyono ${ }^{2}, \&$ Witjaksono ${ }^{2}$ \\ ${ }^{1}$ Department of Plant Protection, Faculty of Agriculture, University of Lampung, Indonesia \\ J1. Prof. Dr. Sumantri Brojonegoro No. 1 Bandar Lampung 35145 \\ ${ }^{2}$ Department of Pest and Plant Disease, Faculty of Agriculture, Universitas Gadjah Mada, Indonesia \\ Bulaksumur, Yogyakarta 55281 \\ E-mail:pramono_sudi@yahoo.com
}

Manuscript received: 14 September 2017. Revision accepted: 19 February 2020

\begin{abstract}
The preferences and distribution of sugarcane scale insect Aulacaspis tegalensis (Hemiptera: Diaspididae) on different clones of sugarcane. This research was conducted in the field of Gunung Madu Plantations Co., Gunung Batin, Lampung Tengah, in the period of April 2015-May 2016. The experiment was arranged in a randomized completely block design with six sugarcane clones as treatments (GMP 1, GMP 2, RGM 99.370, RGM 97.8837, GMP 3, and GMP 4) and four blocks, every block was separated by the street. The abundance of sugarcane scale insects was observed in 15-day intervals from the plant ages of 4 to 12 months. The results showed that sugarcane clone affected the abundance of sugarcane scale insects. After a lag phase of six months (fifth observation), the sugarcane scale insects started being found on all six sugarcane clones in the field. The abundance of the scale insects then increased and peaked at 10.5 months. The sugarcane scale insects attacked all six clones of sugarcane. Clone GMP 1 was the most preferred with an average scale abundance at 814.4 individuals/stem while the least preferred clone was GMP 4 with average of 179 individuals/stem.
\end{abstract}

Key words: abundance, Aulacaspis tegalensis, plant damage, sugarcane

\section{INTRODUCTION}

The sugarcane plantations area in Indonesia are wide enough, however, the productivity is low. In 2015, the sugarcane plantations in Indonesia reached 478,171 ha, covering 287,682 ha belongs to small farmers, 77,207 ha are kept by state companies and 113,282 ha are owned by private companies, with total of national production up to 2,623,931 ton (Direktorat Jenderal Perkebunan, 2015). Sugarcane productivity in Indonesia is relatively low about 67.3 ton/ha with $7.89 \%$ of rendement (Hakim, 2010). In 2014, the rendement decreased and reached only 7\% (Agustine, 2014). The low of sugarcane productivity and its rendement in Indonesia was caused by various aspects such as sugarcane variety, soil fertility, rainfall, and problems of pests and diseases (P3GI, 2008; Greathead, 1970).

Invasion of pests in sugarcane plantations become a serious problem which can significantly reduced the yield of sugarcane. Sunaryo (2003) reported that the main pests in sugarcane are shoot borer (Scirpophaga nivella), stem borer (Chilo auricilius), and scale insect (Aulacaspis tegalensis). The genus of Aulacaspis comprises large number of species which has been reported to be a pest in many cultivated plants (Takagi \& Faferi, 2009; González-Gómez et al., 2016; Affandi et al., 2019). In this recent decades, the invasion of scale insects in sugarcane plantation in Sumatera Island is floating. In Gunung Madu Plantations Co. (PT GMP) Lampung Tengah, the scale insects can be easily found in almost all of the plantations area with $18 \%$ of attack intensity (Sunaryo \& Hasibuan, 2003).

Recently, the scale insects can attack almost all sugarcane varieties causing low to severe damage. The invasion of scale insects in PT GMP is now increasing. One of the reasons is that the sugarcane were cultivated in every planting seasons with different plant age. Windyarini \& Anggraeni (2010) revealed that the scale insects can be effectively managed using pesticide and detergent suspension. However, application of these methods for controlling scale insects in sugarcane is relatively difficult. It is because of the insects are stick to the stem which covered by leaves midribs of the sugarcane. The unremoved leaves midribs will promote breeding of the scale insects (Saefudin, 2014, Head of Entomology Laboratory, personal communication). 
Soemadi (1993) reported that the scale insects which was found in sugarcane at PT GMP was Aulacaspis tegalensis Zehntner (Hemiptera: Diaspididae). This scale insect was first recognized as minor pest, however, since 2000 s, this insect became major pest in PT GMP (Sunaryo \& Widyatmoko, 2002). It has been reported that the scale insect was very destructive and causing severe yield losses (Sunaryo \& Widyatmoko, 2002). At severe attack (more than 50\% attack intensity) will reduce the rendemen from $10.64 \%$ to $2.77 \%$. In low attack intensity (less than $25 \%$ attack intensity) it will produce rendement at $9.18 \%$, meanwhile at medium attack intensity (25-50\% attack intensity), the rendement will be at $6.76 \%$.

The scale insect (A. tegalensis) has not been formerly reported as important pest in sugarcane plantation. However, in 2002-2007, the population of this insect was high in sugarcane plantation at Sugar Group Companies (SGC). Later, it was found that this insect was more destructive than sugarcane stem borer and shoot borer. Attack intensity of the scale insects in the 4 month old of sugarcane was $58.34 \%$. Meanwhile, at 6 month old of sugarcane, the attack intensity reached 63.34\% (Utomo, 2010).

The spread of scale insect is influenced mainly by wind and the presence of ants. Ants becomes the main agent for the spread of the scale insects. The active phase of the insects is in the $1^{\text {st }}$ instar, meanwhile the later instar are in immobile phase. Ecology and the spread of this insect are very important and need to be elucidated as basic information to determine control strategies which will applied in the field (Southwood, 1992). Elliot (1977) \& Southwood (1992) stated that there were 3 types of pest distribution i.e. random, regular, and group distribution. The distribution of scale insect at low level of population was usually in regular distribution $\left(\sigma^{2}<\mu\right)$. The distribution of the scale insect will be changed in line with the plant growth. The more plant grow, the more number of scale insect population, later they will produce group distribution pattern, with higher population density following negative binomial distribution $\left(\sigma^{2}>\mu\right)$.

This research was performed to investigate the influence of sugarcane clone or variety to the population density and attack intensity of scale insect on sugarcane. The study covered the development of scale insect (A. tegalensis) in different age of plants, distribution of the scale insect population, and attack intensity of the scale insect on sugarcane at PT GMP, Gunung Batin, Lampung Tengah.

\section{MATERIALS AND METHODS}

Research Site. Observation was performed at PT GMP, Gunung Batin, Lampung Tengah, from April 2015 to May 2016. The study was arranged using randomized completely block design (RCBD). The treatments were clones of sugarcane with 4 repetitions (blocks). Each block were area of sugarcane plantations which in the range of $11-12.5$ ha in size. Observation of the scale insects was conducted on 6 sugarcane clones namely GMP 1, GMP 2, RGM 99.370, RGM 97.8837, GMP 3, and GMP 4 started at 4 to 12 month old of plants with 15 days of interval.

Determination of The Plant Samples. Observation of the scale insects was conducted using systematic method. As many as 45 plants showed plant height and stem size which were relatively same were chosen in each clones as plant sample. The first plant samples was chosen using purposive method (plants showed plant height and stem size which were relatively same) and then moved to the next 17 plant following the plant row. The sheath of the chosen plant was removed and the scale insects were counted using hand-tally counter, started from the first segment to the top of the plant. Number of segment where the scale insects were found and total segment found in the whole stem were also recorded.

Attack intensity of the scale insects (Tp) was determined using formula:

$$
\mathrm{Tp}=\frac{\mathrm{a}}{\mathrm{b}} \times 100
$$

$\mathrm{a}=$ total segment in each plant samples where the scale insects were found

$\mathrm{b}=$ total segment in the whole plant

Data Analysis. Population and attack intensity of the scale insects were analyzed using analysis of variance (ANOVA) followed by least significant difference (LSD) analysis. Correlation between population and attack intensity of the scale insects was performed using linear regression analysis. ANNOVA was conducted using 1 or $5 \%$ of significant level, meanwhile the LSD analysis was performed using 5\% of significant level. Regression analysis was conducted by F test with 1 or $5 \%$ of significant level.

Distribution of the scale insects population was analyzed by comparing variance and average of the samples in each varieties or clones. Comparison of the variance and average of the samples was achieved using 
$\mathrm{Z}$ test at $5 \%$ of significant level. The $\mathrm{Z}_{\text {value }}$ was determined using formula (Sudarsono, 2015):

$$
Z_{\text {value }}=\frac{\bar{x}-s^{2}}{s \sqrt{n}}
$$

$\bar{x}=$ average of the arthropods populations,

$\mathrm{s}^{2}=$ variance of the arthropods populations

$\mathrm{n}=$ repetition

The value $\bar{x}_{\text {of }}$ is the estimator of $\mu$ while the value of $\mathrm{s}^{2}$ is the estimator of $\sigma^{2}$.

\section{RESULTS AND DISCUSSION}

The scale insects was initially found in the field at 6 months old of sugarcane with low population density, ranged of 0.11-0.19 individuals/plant. The abundance of the scale insects was continue to raise and the highest was observed when the plant reached 10.5 months old. After it reached the peak, the population of the scale insects was decrease until the sugarcane almost ready to be harvested or when the plant at 12 months old (Figure 1). The abundance of the scale insects was difference among clones since the plant at 7.5 months old.

The GMP 1 clone were showed the highest abundance of the scale insect population. This clone was also resulted the highest value on the increase of scale insect population. In the age of 8-9 months, the abundance of the scale insects in the GMP 1 were much higher than the other clones. The symptom due to scale insect on GMP 1 could also be clearly recognized with the yellow color or dried leaves even the midrib was still stick to the stem. The segment of GMP 1 where the scale insects was found showed less of freshness and appeared dirty. Moreover, several plants of GMP 1 (aged from 10-11 month) were dead due to this scale insects.

The abundance of the scale insects in the other 5 clones were varied. The abundance of the scale insects on GMP 2 was not significantly difference with RGM 99.370, however it was significantly higher than RGM 97.8837, GMP 3, and GMP 4. The abundance of the scale insects on RGM 99.370 was also significantly higher than those on RGM 97.8837, GMP 3, and GMP 4.

The GMP 1 clone was seem to be the most liked by the scale insects followed by GMP 2, RGM 99.370, and RGM 97.8837. The GMP 3 and GMP 4 were relatively not liked by the scale insects, there was no symptom due to scale insects found in these two clones. As for GMP 1, before it was harvested, the attacked stem were dry and porous. In the case of GMP 2, the attack of the scale insects in this clone was not so high, even some of the stems were dry. The RGM 99.370 and RGM 97.8837 relatively tolerant and there was no dry stem due to scale insects attack observed in the field. The GMP 3 and GMP 4 was seem to be resistant

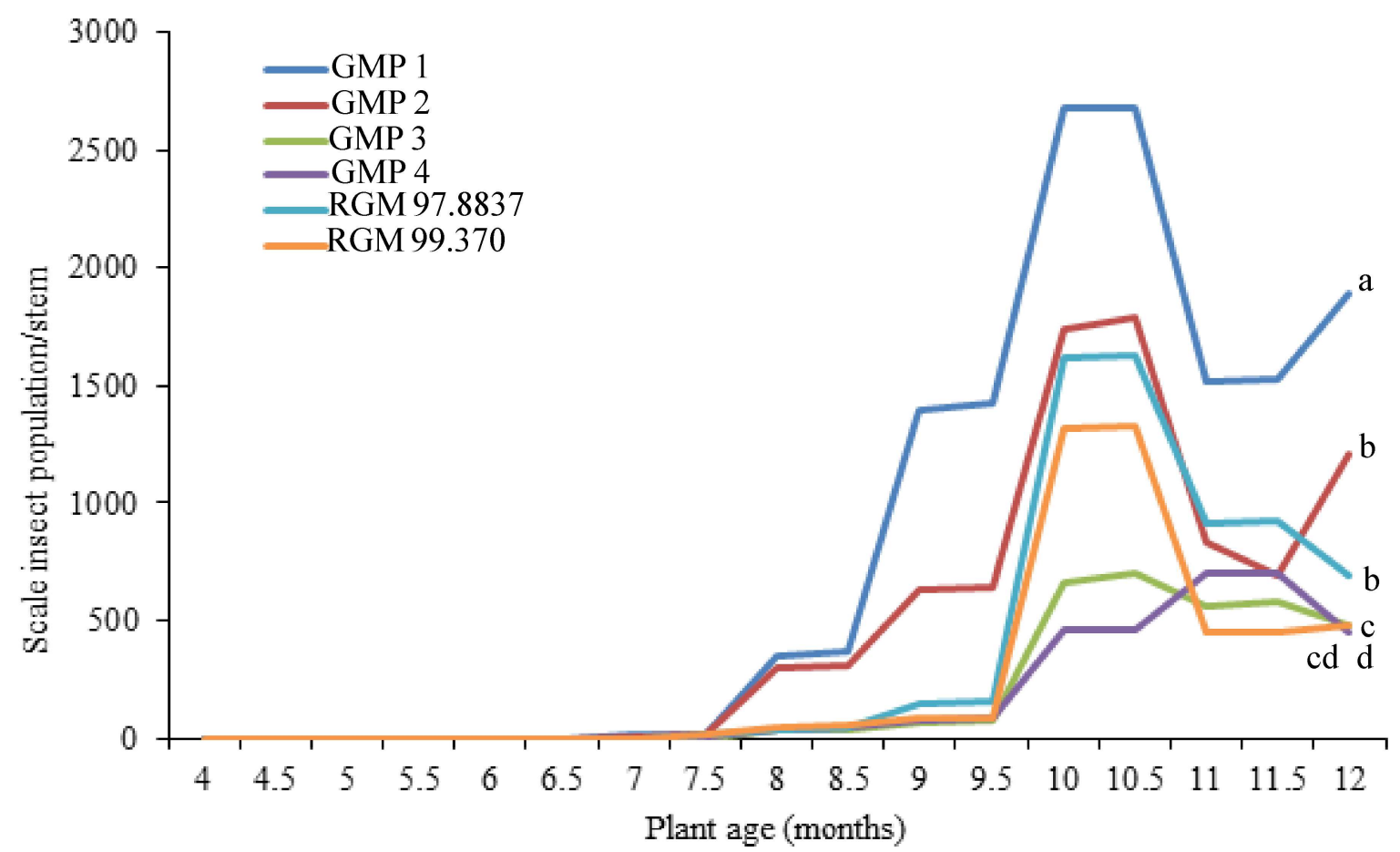

Figure 1. Fluctuation of the scale insects population (A.tegalensis) on the six different sugarcane clones. 
to the scale insects. Both of these clones did not show any symptom due to the attack of scale insects, either yellow leaves or dry stem.

Linear regression analysis performed between plant age and attack intensity of the scale insects in each clones showed significant difference (Figure 2). The GMP 1 produced the highest attack intensity than GMP 2, RGM 99.370, RGM 97.8837, GMP 3, and GMP 4.

The character of GMP 1 were tight and difficult to open midribs, was preferred by the scale insects. This made the population of the scale insects found in GMP 1 were the highest in all of clones. The average population of the scale insect in the age of 4 months to harvest time was 814.4 individuals/plant, meanwhile the total individuals of the scale insects until harvest time were 14,909.10 individuals. If we compare with the varieties with the easier open midribs (RGM 97.8837, GMP 3, and GMP 4) or partially opened (RGM 99.370 and GMP 2 ), the population was significantly different. The scale insects population on the clones which its midribs were easier to open at 4 months old to harvest time was in the ranged of 179.0-255.2 individuals/stem. The development of the scale insects population is shown in Figure 1.

The spread of the scale insects in the field were relatively equal in each clones, however, the development of the scale insects population were different for each clones in certain age of the plant. The highest population of the scale insects was found in GMP 1 and GMP 2 and the lowest population was found in GMP 4. The peak of the scale insect population in all clones was observed when the plants are in the age of 10-11 month. After this age, the population density was relatively decreased. It was due to the presence of natural enemies either predators or parasitoids which can suppress the scale insects population.
Generally, GMP 1 were the most liked by the scale insects. Average population found in this clone in 12 months was 14,909.10 individuals/stem, followed by GMP 2 with 8962.14 individuals/stem, RGM 99.370 with 6686.19 individuals/stem, and the two clones which were less liked by the scale insects namely RGM 97.8837 and GMP 3 with 4672.77 individuals/stem and 3483.89 individuals/stem, respectively. Among the six varieties or clones used in this study, the most disliked variety by the scale insects was GMP 4 with the average population is 3280.49 individuals/stem.

Saefudin (2017) reported that variety or clone which was not liked by the scale insects was the clone which its midribs were relatively difficult to open. This may related with the presence of the natural enemies, both predators and parasitoids. The easily open midribs will give bigger change to predators or parasitoids to reach the scale insect than those with the difficult to open midribs. Preference of the scale insects to RGM 99.370 and RGM 97.8837 was relatively low. The RGM 99.370 was clone that has slightly open midribs and RGM 97.8837 was clone that has open midribs. The GMP 3, GMP 4, and RGM 97.8837 has easily open midribs. Resistance level of the sugarcane varieties or clones used in this study is shown in Table 1.

Attack intensity of the scale insects on GMP 1 was observed at $10^{\text {th }}$ month which was reached $99.35 \%$ (Figure 2). It revealed that the scale insects were found in almost all of the plant segments, although with different population density. Generally, population of the scale insects in the upper plant were lower than those in the middle or the lower part of the plant. The average of the scale insects attack intensity on GMP 1 at 4 to 12 months old was $34.57 \%$. Sunaryo \& Widyatmoko (2002) reported that because of this attack intensity, the rendement was decreased from 8.12 to $6.76 \%$.

Table 1. Characters on the clones of sugarcane*

\begin{tabular}{|c|c|c|c|c|c|}
\hline \multirow{2}{*}{ Clone } & \multicolumn{3}{|c|}{ Productivity } & \multirow{2}{*}{$\begin{array}{l}\text { Midribs } \\
\text { stickness }\end{array}$} & \multirow{2}{*}{$\begin{array}{l}\text { Response to } \\
\text { the scale insects }\end{array}$} \\
\hline & $\mathrm{TCH}^{* *}$ & Rendement (\%) & Fiber level (\%) & & \\
\hline GMP 1 & 115 & 8.12 & 15.52 & Sticked & Susceptible \\
\hline GMP 2 & 111 & 8.24 & 14.40 & Moderate sticked & Moderate \\
\hline GMP 3 & 119 & 8.18 & 15.48 & Open & Resistant \\
\hline GMP 4 & 119 & 8.43 & 14.44 & Open & Resistant \\
\hline RGM 99.370 & 104 & 7.90 & - & Moderatly open & Moderate \\
\hline RGM 97.8837 & 112 & 9.24 & - & Open & Moderate \\
\hline
\end{tabular}

*) Source: Research and Development PT GMP (2017)

**) $\mathrm{TCH}=$ Ton Cane per Hectare 

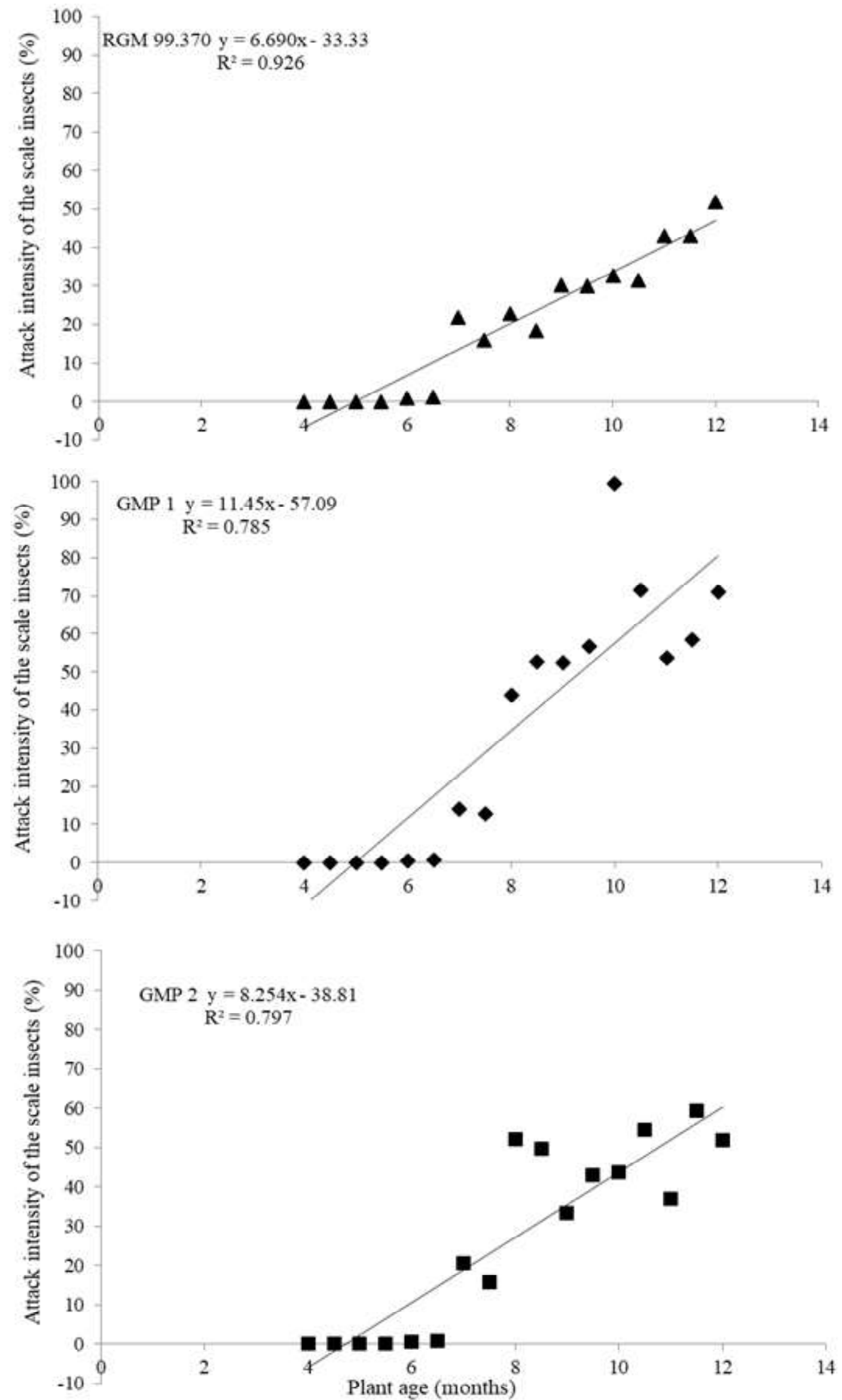

Figure 2. Regression analysis of plant age and attack intensity of the scale insects 

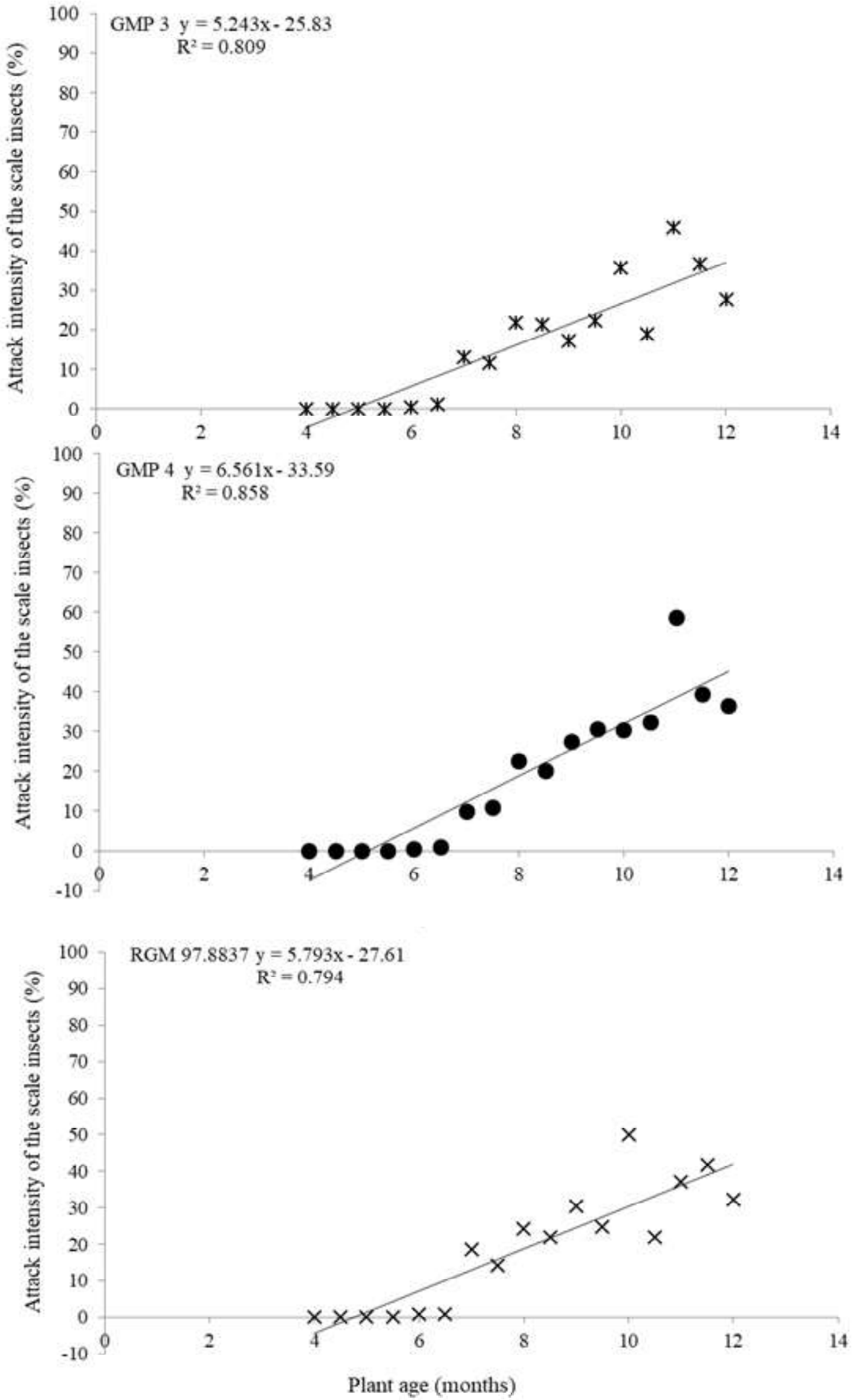

Figure 2. (Continued) 
In the case of RGM 99.370, RGM 97.8837, GMP 3 , and GMP 4, average attack intensity resulted by these varieties or clones were in the ranged of $16.11-20.19 \%$. This attack intensity was relatively low, because it is still lower than $25 \%$ and only caused small amount of yield losses. Sunaryo \& Widyatmoko (2002) stated that, with those small level of attack intensity, the decreased of the rendemen obtained can still be tolerated.

In the age of 10.5 months, attack intensity of the scale insects on GMP 1 was relatively high $(71.07 \%)$ compared to GMP 2, RGM 99.370, RGM 97.8837, GMP 3 , and GMP 4, which showed attack intensity at less than $52 \%$, there even $27.69 \%$ attack intensity. The high attack intensity in the GMP 1 was caused by inability of the natural enemies to suppress population of the scale insects. This because the midribs in the GMP 1 was relatively difficult to open. Attack intensity of the scale insects per stem is shown in Figure 2.

The scale insects are living inside the midribs and the remaining sugarcane in every harvest time. The scale insects were initially observed on the sugarcane in the age of 4-5 months with low population density, however in this study we found that in the age of 5.5 there was no scale insects observed in the field.

The presence of scale insects was difficult to be recognized because of its small size and their habitat. They live in place where it is difficult to reach i.e. between stem or in the midribs of sugarcane. The sugarcane with low population (less than 100 individuals/ stem) did not show any symptom, the plant showed normal growth. The symptom was initially observed when the population reached hundreds individuals/stem, showed yellowing leaves and in the severe attack it will cause the dead of the plants. The attacked sugarcane will produce symptom at 8 month old and will die at 10 month old.

The scale insects in the sugarcane may originated from the remaining sugarcane obtained from previous season or it was spread by wind or ants. The scale insects will stay in the plant when the segment was formed and the presence of midribs which those in the age of 4-6 months.

\section{CONCLUSION}

GMP 1 clone was most preferred by the scale insects rather than GMP 2, RGM 99.370, RGM 97.8837, GMP 3, and GMP 4. Average of the scale insects population was 814.4 individuals/stem. The lowest population was observed in GMP 4 which was reached 179 individuals/stem. The highest attack intensity was observed in GMP 1 and GMP 2. In the age of 10 month, almost all the segment in GMP 1 was attacked by scale insects with attack intensity reached $99.35 \%$ /segment.

\section{ACKNOWLEDGMENT}

The data used in this manuscript is part of dissertation submitted to Graduate School of Agricultural Science, Faculty of Agriculture, Universitas Gadjah Mada, Yogyakarta. We do thanks to Mr. Saefudin, Mr. Tri Agus and all the staff in the Research and Development of PT Gunung Madu Plantation for technical support.

\section{REFERENCES}

Affandi, Lististio D, Santoso PJ, Mansyah E, \& Sartiami D. 2019. Identification, distribution and abundance of scale insect associate with several clones of durian (Durio zibethinus Merr.). Agrivita 41(2): 206-212.

Agustine I. 2014. Produksi Gula 2014: Meleset dari Angka Taksasi. Bisnis com. https:// ekonomi.bisnis.com/read/20141215/99/382919/ produksi-gula-2014-meleset-dari-angka-taksasi). Accessed on 30 March 2015.

Direktorat Jenderal Perkebunan. 2015. Statistik Perkebunan Indonesia. Departemen Pertanian, Direktorat Jenderal Perkebunan. Jakarta.

Elliott JM. 1977. Some Methods for the Statistical Analysis of Samples of Benthic Invertebrates. 2nd Edition. Freshwater Biological Association. Scientific Publication No. 25. University of California, Oakland.

Greathead DJ. 1990. Crawler behaviour and dispersal. In: Rosen D (Ed.). World Crop Pests, Armored Scale Insects, their Biology, Natural Enemies and Control. pp. 305-308. Elsevier Science, Amsterdam.

González-Gómez R, Riverón-Giró FB, García-González A, Martínez-Rosas R, \& Solís-Montero L. 2016. First report of Aulacaspis yasumatsui (Hemiptera: Diaspididae) in Mexico. Florida Entomologist 99(3): 583-584.

Hakim M. 2010. Potensi sumber daya lahan untuk tanaman tebu di Indonesia. J. Agrikultura. 21(1) : 5-12.

Indonesian Sugar Research Institute (P3GI). 2008. Konsep Peningkatan Rendemen Tebu untuk 
Mendukung Program Akselerasi Industri Gula Nasional. https://www.slideshare.net/ wong_tjoekir/konsep-peningkatanrendemen. Accessed on 9 October 2013.

Research and Development PT Gunung Madu Plantations. 2017. Karakteristik Klon/Varietas Tebu. Publikasi Intern. PT. Gunung Madu Plantations, Lampung.

Soemadi D. 1993. Hama-hama Penting Tebu di Indonesia. P3GI, Pasuruan.

Southwood TRE. 1992. Ecological Methods. Chapman $\&$ Hall, London.

Sudarsono H. 2015. Pengantar Pengendalian Hama Tanaman. Universitas Lampung, Bandar Lampung.

Sunaryo \& Widyatmoko K. 2002. Serangan kutu perisai dan dampaknya kepada beberapa parameter produksi tanaman tebu di Gunung Madu. Prosiding Pertemuan Teknis P3GI. pp. 1- 5. Pasuruan.

Sunaryo. 2003. Mempelajari Serangan Hama Penggerek Batang di Lapang pada Berbagai
VarietasTebu di Gunung Madu. Lampung Tengah.

Sunaryo \& Hasibuan R. 2003. Perkembangan populasi kutu perisai Aulacaspis tegalensis Zehntner (Homoptera: Diaspididae) dan pengaruh tingkat serangannya terhadap penurunan hasil tebu di PT. Gunung Madu Plantation, Lampung Tengah. $J$. HPT Tropika. 3(1): 1-5.

Takagi S \& Faveri SD. 2009. Notes on scale insects of Aulacaspis associated with mangroves and cycads (Sternorrhyncha: Coccoidea: Diaspididae). Insecta Matsumurana. New Series: Journal of the Faculty of Agriculture Hokkaido University, Series Entomology 65: 101-129.

Utomo AP. 2010. Populasi Hama Kutu Perisai (Aulacaspis tegalensis) pada Berbagai Klon dan Umur Tanaman. Skripsi. Institut Pertanian STIPER, Yogyakarta.

Windyarini E \& Anggraeni I. 2011. Kutu sisik pada cendana (Santalum album L.) di Kupang, Nusa Tenggara Timur. J. Penelitian Hutan Tanaman 8(1): 51-58. 